\title{
Personal Hygiene and Safety among governmental Hospitals Nurses Staff in Mosul City
}

\author{
Rami Ramadan Allo ${ }^{1}$, Tameem Thamir Mayouf ${ }^{2}$, Munther Natheer AL-Fattah ${ }^{3}$ \\ ${ }^{1}$ Mosul University, College of Nursing, Mosul, Iraq
}

\begin{abstract}
Objective: The present study aimed to knowing weak points which is lead to negligence it could be transmission of nosocomial infection.

Material and Method: The sample of the study included 100 nurses were selected randomly from the pediatric, surgical, emergency, I.C.U and operation room departments in AL-Salam and AL-Jamhory Teaching Hospitals in the Mosul City during a period which extended from the $1 / 10 / 2018$ to $20 / 1 / 2019$, the data were collected through an observation of each subject of the sample during working with the patients and fulfill in the checklist sheet.
\end{abstract}

Result: The findings of this research revealed significant values between gender and personal hygiene practices to the advantage of female, also there is significant relationship between level of education and personal hygiene practices to the advantage of colligate nurses.

Conclusion: the present study demonstrated that there was negligence in some personal hygiene practices among nurses such as (hand washing, use protective devices, use protective measures, and hepatitis B vaccination).

Keywords: hygiene, safety, nurses staff

\section{Introduction}

we can be prevented and controlled Transmission of infections in health care system through the implementation of special precautions which can be standard and basic precautions, which must be applied to all cases from the admission to hospital until discharge, regardless types of diagnosis or infectious degree, and addition (transmission-method ). (1) The patient's care managements in the health facility should be the same level of a "Standard precaution" applied work practices that are essential to formulate a high level of patient's protection, patient's visitors, and health care practitioner.

Warnings points to prevent infection transmission include the following:

hand washing and antisepsis (hand hygiene),use of personal protective like gloves, masks and equipment when handling blood samples and body secretions pay attention when handling of surgical care equipment and soiled linen, protection of needle stick and knife sharp injuries, environmental management, cleaning from pollution; and recycled of waste. ${ }^{(2)}$ the Infection can be control for most factors which that influencing to the transmission of infection between patients or health workers by using a prophylaxes method starting from hand washing, to all body hygiene and vaccination ${ }^{(3-9)}$ Many researchers and studies have been seeking over the world health centers about nosocomial infection which are reviled careless to nosocomial infection control and no standards precaution in multi countries. Our research aimed to study the personal hygiene of health care giver staff. In addition the objective was to identify weak points which could lead to transmission of nosocomial infections.

\section{Methodology}

Descriptive study design depended to, 100 nurses were selected randomly from the pediatric and carried out that study in, surgical, emergency, I.C.U and operation room departments in (AL-Salam and AL-Jamhory Teaching Hospitals in the Mosul City 
during a period which extended from the 1/10/2018 to $20 / 1 / 2019$. Data were collected by checklist, which is as a guidelines and reference to established ${ }^{(8,9)}$. A questionnaires format consists of multiple fields and items as the purpose of this study. Checklist papers tested to pilot study in two hospitals on ten nurses to discover any problems and modified according to results. Data were collected through an observation of each subject of the sample during working with the patients and fulfill in the checklist sheet. To describe and analyze the findings of the study, SPSS program (version 17) was used to analyze the data by using mean, percentage, and ANOVA test at $\mathrm{P} .=0.05$.

\section{Results}

Table (1) Demographical characteristics of the study sample

\begin{tabular}{|c|c|c|}
\hline Sex & No. & $\%$ \\
\hline Male & 53 & $53 \%$ \\
\hline female & 47 & $47 \%$ \\
\hline Age & No. & $\%$ \\
\hline Less than 25 & 5 & $5 \%$ \\
\hline $25-29$ & 44 & $44 \%$ \\
\hline $30-34$ & 19 & $19 \%$ \\
\hline $35-39$ & 13 & $13 \%$ \\
\hline More than 40 & 19 & $19 \%$ \\
\hline Place of work & No. & $\%$ \\
\hline I.C.U & 20 & $20 \%$ \\
\hline Pediatric & 20 & $20 \%$ \\
\hline Surgical & 20 & $20 \%$ \\
\hline Emergency & 20 & $20 \%$ \\
\hline Operation room & 20 & $20 \%$ \\
\hline Years of experiences & No. & $\%$ \\
\hline Less than 5 & 38 & $38 \%$ \\
\hline $5-10$ & 32 & $32 \%$ \\
\hline More than 10 & 30 & $30 \%$ \\
\hline Graduate of & No. & $\%$ \\
\hline Nursing school & 4 & $4 \%$ \\
\hline preparatory nursing & 18 & $18 \%$ \\
\hline Institute & 38 & $38 \%$ \\
\hline College & 40 & $40 \%$ \\
\hline
\end{tabular}

Table-1- reveals that (53\%) of the sample were males, (44\%) of the sample were between (25-29) years of age, (38\%) of them had experiences less than (5 years), and (40\%) of them had bachelor degree in nursing science 
Table (2) checklist scores for personal hygiene practices among nurses

\begin{tabular}{|c|c|c|}
\hline \multirow{2}{*}{ Practice } & \multicolumn{2}{|c|}{ Frequency } \\
\hline & Yes & No \\
\hline Use uniform according to hospital policy & 96 & 4 \\
\hline Uniforms are clean & 78 & 22 \\
\hline Use proper shoes (not slippers) & 96 & 4 \\
\hline Have short fingernails & 80 & 20 \\
\hline Do not wear jewellery (rings/bracelets) & 78 & 22 \\
\hline Use needle-cutter or specific container to discard used syringes, needles and other sharp items & 100 & 0 \\
\hline Wash hands before contact with patients & 40 & 60 \\
\hline Wash hands after each step of working & 80 & 20 \\
\hline Wash hands after contact with patients & 40 & 60 \\
\hline Wear gloves when needed & 40 & 60 \\
\hline $\begin{array}{l}\text { Use protective devices (gown, mask, gloves and goggles) when in contact with infectious patients } \\
\text { or if there is possibility of splashing blood or other drainages }\end{array}$ & 40 & 60 \\
\hline Use protective measures if drawing blood (gloves, masks and goggles) & 22 & 78 \\
\hline Hepatitis B vaccination complete ( 3 times) & 50 & 50 \\
\hline
\end{tabular}

Table -2- shows that $96 \%$ of the sample wear uniform according to hospital policy, $78 \%$ from them own uniform are clean, $96 \%$ use proper shoes, $80 \%$ of keep short fingernails, $78 \%$ not wear jewellery, $100 \%$ from the sample uses specific container to discard used syringes, $60 \%$ from them didn't wash their hand before contact the patients, $80 \%$ from them wash hands after contact the patients, $60 \%$ didn't wear gloves and never use protective devices when contact with infectious patients, $78 \%$ of nurses didn't use protective measures when drawing blood, Finally $50 \%$ from the sample didn't take Hepatitis B vaccine.

Table (3) Comparison of the differences between nurse's practice regarding hand hygiene rate and their gender.

\begin{tabular}{|c|c|c|c|c|c|c|c|}
\hline Practice & sex & No & $\mathbf{X}$ & SD & DF & T.obs & P.value \\
\hline \multirow{2}{*}{$\begin{array}{l}\text { Personal } \\
\text { hygiene }\end{array}$} & Male & 53 & 3.3 & 1.4 & \multirow{2}{*}{98} & \multirow{2}{*}{1.5} & \multirow{2}{*}{ N.S } \\
\hline & female & 47 & 3.5 & 1.4 & & & \\
\hline \multirow{2}{*}{ Hand wash } & Male & 53 & 3.4 & 2.2 & \multirow{2}{*}{98} & \multirow{2}{*}{0.04} & \multirow{2}{*}{$\mathrm{S}$} \\
\hline & female & 47 & 3.5 & 2.1 & & & \\
\hline \multirow{2}{*}{$\begin{array}{l}\text { Contact with } \\
\text { patients }\end{array}$} & Male & 53 & 4.3 & 1.7 & \multirow{2}{*}{98} & \multirow{2}{*}{0.03} & \multirow{2}{*}{$\mathrm{S}$} \\
\hline & female & 47 & 4.8 & 1.8 & & & \\
\hline \multirow{2}{*}{$\begin{array}{l}\text { Protective } \\
\text { measurement }\end{array}$} & Male & 53 & 1.6 & 1.0 & \multirow{2}{*}{98} & \multirow{2}{*}{0.8} & \multirow{2}{*}{ N.S } \\
\hline & female & 47 & 1.4 & 1.0 & & & \\
\hline \multirow{2}{*}{ Vaccine } & Male & 53 & 2.9 & 1.9 & \multirow{2}{*}{98} & \multirow{2}{*}{1.6} & \multirow{2}{*}{ N.S } \\
\hline & female & 47 & 3.2 & 1.6 & & & \\
\hline
\end{tabular}

T critical $=1.9$ 
Table (3) shows that there was statically significant differences between hand hygiene rates and the gender of staff at $\mathrm{p}$ value $=0.05$.

Table (4) one - way analysis of variance for the difference between hand hygiene practice by nurses and their age

\begin{tabular}{|c|c|c|c|c|c|}
\hline Practice & S.O.V & SS & DF & MS & F.obs \\
\hline \multirow{3}{*}{ Personal hygiene } & Between Groups & 1.630 & 4 & 6.157 & \\
\hline & Within Groups & 16.530 & 95 & \multirow{2}{*}{1.753} & 1.011 \\
\hline & Total & 17.160 & 96 & & \\
\hline \multirow{3}{*}{ Hand wash } & Between Groups & 1.712 & 4 & 18.893 & \\
\hline & Within Groups & 22.288 & 95 & \multirow{2}{*}{5.269} & 1.053 \\
\hline & Total & 24.000 & 96 & & \\
\hline \multirow{3}{*}{$\begin{array}{l}\text { Contact with } \\
\text { patients }\end{array}$} & Between Groups & 1.712 & 4 & 18.893 & \\
\hline & Within Groups & 22.288 & 95 & \multirow{2}{*}{5.269} & 1.053 \\
\hline & Total & 24.000 & 96 & & \\
\hline \multirow{3}{*}{$\begin{array}{l}\text { Protective } \\
\text { measurement }\end{array}$} & Between Groups & 1.359 & 4 & 14.165 & \\
\hline & Within Groups & 15.801 & 95 & \multirow{2}{*}{3.432} & 0.843 \\
\hline & Total & 17.160 & 96 & & \\
\hline \multirow{3}{*}{ vaccine } & Between Groups & 1.936 & 4 & 18.893 & \multirow{3}{*}{$\begin{array}{l}2.585 \\
\text { N.S }\end{array}$} \\
\hline & Within Groups & 24.064 & 95 & \multirow{2}{*}{5.269} & \\
\hline & Total & 26.000 & 96 & & \\
\hline
\end{tabular}

\section{F critical $=3.32$}

Table -4-demonstrate that there were no statically differences with regards nurse's hand hygiene rates and their age at $\mathrm{p}$ value $=0.05$.

Table -5-one - way analysis of variance for the difference between nurse's practice regarding hand hygiene rates and their level of education.

\begin{tabular}{|l|l|l|l|l|l|}
\hline Practice & S.O.V & SS & DF & MS & F. obs \\
\hline \multirow{3}{*}{ Personal hygiene } & Between Groups & 3.712 & 3 & 8.720 & \multirow{3}{*}{5.011} \\
\cline { 2 - 5 } & Within Groups & 22.288 & 96 & \multirow{2}{*}{ S } \\
\cline { 2 - 5 } & Total & 26.000 & 99 & & \multirow{2}{*}{19.653} \\
\hline \multirow{3}{*}{ Hand wash } & Between Groups & 9.132 & 3 & \multirow{2}{*}{ S } \\
\cline { 2 - 4 } & Within Groups & 14.868 & 96 & & \\
\cline { 2 - 5 } & Total & 24.000 & 99 & & \\
\hline
\end{tabular}


Cont... Table -5-one - way analysis of variance for the difference between nurse's practice regarding hand hygiene rates and their level of education.

\begin{tabular}{|c|c|c|c|c|c|}
\hline \multirow{3}{*}{$\begin{array}{l}\text { Contact with } \\
\text { patients }\end{array}$} & Between Groups & 9.132 & 3 & 3.044 & \multirow{3}{*}{$\begin{array}{l}19.653 \\
\mathrm{~S}\end{array}$} \\
\hline & Within Groups & 14.868 & 96 & \multirow{2}{*}{0.155} & \\
\hline & Total & 24.000 & 99 & & \\
\hline \multirow{3}{*}{$\begin{array}{l}\text { Protective } \\
\text { measurement }\end{array}$} & Between Groups & 1.392 & 3 & 1.464 & \multirow{3}{*}{$\begin{array}{l}13.875 \\
\mathrm{~s}\end{array}$} \\
\hline & Within Groups & 15.768 & 96 & \multirow{2}{*}{0.164} & \\
\hline & Total & 17.160 & 99 & & \\
\hline \multirow{3}{*}{ vaccine } & Between Groups & 8.26 & 3 & 2.675 & \multirow{3}{*}{$\begin{array}{l}15.132 \\
\mathrm{~s}\end{array}$} \\
\hline & Within Groups & 16.974 & 96 & \multirow{2}{*}{0.177} & \\
\hline & Total & 25.000 & 99 & & \\
\hline
\end{tabular}

F critical $=3.78$

Table -5- revile that a significant differences for nurse's hand hygiene rates and their level of education at $(p$ value $=0.05$. the majority of staff had bachelor degree in nursing science.

Table (6) one - way analysis of variance for the difference between nurse's hand hygiene rates and their years of experience.

\begin{tabular}{|c|c|c|c|c|c|}
\hline Practice & S.O.V & SS & DF & MS & F. obs \\
\hline \multirow{3}{*}{ Personal hygiene } & Between Groups & 3.330 & 2 & 6.975 & \multirow{3}{*}{$\begin{array}{l}6.311 \\
S\end{array}$} \\
\hline & Within Groups & 16.830 & 97 & \multirow{2}{*}{2.987} & \\
\hline & Total & 20.160 & 99 & & \\
\hline \multirow{3}{*}{ Hand wash } & Between Groups & 0.163 & 2 & 113.907 & \multirow{3}{*}{$\begin{array}{l}10.653 \\
\mathrm{~S}\end{array}$} \\
\hline & Within Groups & 23.837 & 97 & \multirow{2}{*}{10.454} & \\
\hline & Total & 24.000 & 99 & & \\
\hline \multirow{3}{*}{$\begin{array}{l}\text { Contact with } \\
\text { patients }\end{array}$} & Between Groups & 9.132 & 2 & 3.044 & \multirow{3}{*}{$\begin{array}{l}19.653 \\
S\end{array}$} \\
\hline & Within Groups & 14.868 & 97 & \multirow{2}{*}{0.155} & \\
\hline & Total & 24.000 & 99 & & \\
\hline \multirow{3}{*}{$\begin{array}{l}\text { Protective } \\
\text { measurement }\end{array}$} & Between Groups & 0.181 & 2 & 8.500 & \multirow{3}{*}{$\begin{array}{l}5.166 \\
S\end{array}$} \\
\hline & Within Groups & 16.979 & 97 & \multirow{2}{*}{1.645} & \\
\hline & Total & 17.160 & 99 & & \\
\hline \multirow{3}{*}{ vaccine } & Between Groups & 0.219 & 2 & 29.565 & \multirow{3}{*}{$\begin{array}{l}5.536 \\
S\end{array}$} \\
\hline & Within Groups & 24.781 & 97 & \multirow{2}{*}{5.341} & \\
\hline & Total & 25.000 & 99 & & \\
\hline
\end{tabular}

F critical $=4.6$

Table -6- shows that there were a significant differences between nurse's hand hygiene rates and the years of experience at $\mathrm{p}$ value $=0.05$. 


\section{Discussion}

Since the era of Islamic message, Islam religion encouraged people to maintain personal hygiene especially hand washing before and after eating, before and after use of toilet to prevent transmission of disease from one person to others. (2), Florence Nightingale in 1854 was stated the relationship between nursing performance and infection control that was first identified during the Crimean war, when she worked at a military hospital in Scutari/ Italy, the services in that hospital was too bad . Nightingale's notes and her believes in this health facility led her to believe the enhancing hygienic conditions would decrease the number of deaths. "championed the cause of improved hygiene, food, and living conditions for the hospitalized soldiers she attacked the hospital conditions and called for basic public health, infection control measures, cleanliness, hygiene and education about the importance of the issue" . The confirmation was come from Jean Lawrence, which is chairman of the Infection Control Nurses Association (ICNA) he also said that Florence Nightingale was maybe the first nurse mentioned to infection control without recognized it ${ }^{(8)}$. Now the nursing staff are the key which are players the important role during heath care to ensure the survival of infection control. (7). Nosocomial infection control is conceder important for three main cusses : the first one to avoiding transmission of infections from patients to health care provider staff and from them to patients, second one to development the bacterial support and resistance, finally to limitation of financial consuming resources ${ }^{[9,10]}$. in 3 ways could be Transmission of nosocomial infections in hospitals, from patient to patient, patient to health staff and health caregivers to patients ${ }^{[11]}$. A huge reason for transporting of microorganisms is because forgetting hand washing, protective devices such as gloves and masks and a weak of personal hygiene in HCWs, in particularly improper disposal of sharp tools, ${ }^{[12]}$. The major findings of this study were as follows: hand washing compliance was significantly higher among female nurses $(\mathrm{p}=0.04)$ than male nurse (see Table-3).This finding is supported by the study of (Askarian, 2014) which concluded" that the Female nursing staff in CCU unit pay attention to hand washing significantly more than males after patient care contact. ${ }^{(4)}$ [Malekzadeh, 2015], said that inter gender behaviours differences with regard hand washing may be as a result of basic differences in the education of parents on hand hygiene for girls and boys. However females were more look after. Which also add more support to this result. Similar findings have been stated, that led us to think females were more likely to wash their hands than male in $\mathrm{HCWs}^{[5]}$. The study also revealed slightly significant relationship between the level of education and hand washing $(\mathrm{p}=0.04)$, majority of the staff $(\% 40)$ were staff nurses which had bachelor degree (see Table-4). This results is a similar with the study did in Italy ${ }^{[6]}$ which stated that "nurses how are graduated from a higher level of education and with a higher knowledge of risk a transmitting and infectious disease as well as during working were more focusing to doing appropriate antisepsis of the surgical wound with hand washing pre and post medication care.$^{[13]}$. [Health centre, 2016] suggested that to be careful a high level of hand cleanses adherence, HCWs need education, clear guide notes, and some understanding to infection complications. This study reveals also that there were statistically significant difference between years of experience and hand washing practice (see Table-6). While the exact reasons for these observed patterns are not clear, several possibilities exist. The first, are that of all health care settings put a lot of effort to make sure that all staff should compliance with WHO Quid lines of hand washing whenever contact with the patients., the second is that the dramatically increase in the number of high educated nursing staff.

\section{Conclusion}

Hand washing is important. This study has shown that there was negligence in some personal hygiene practices among nurses such as (hand washing, use protective devices, use protective measures, and hepatitis $B$ vaccination).

Ethical Clearance: The Research Ethical Committee at scientific research by ethical approval of both environmental and health and higher education and scientific research ministries in Iraq

Conflict of Interest: The authors declare that they have no conflict of interest.

Funding: Self-funding

\section{References}

1. Chandra PN, Milind K. Lapses in measures recommended for preventing hospital acquired infection. Journal of hospital infection, 2014, 47:218-22.

2. Gooran NR et al. National nosocomial infection surveillance system based study in Iran: additional 
hospital stay attributable to nosocomial infections. American journal of infection control, 2013, 31:465-8.

3. Askarian $\mathrm{M}$ et al. Incidence of urinary tract and blood stream infections in Ghotbeddin Burn Center, Shiraz. Burns, 2013, 29:455-9.

4. Askarian $\mathrm{M}$ et al. Infection rate and outcome of female burn patients in Shiraz, Iran. American journal of infection control, 2014, 33:23-6.

5. Malekzadeh R. Viral hepatitis. In: Azizi F, Janghorbani M, Hatami H, eds. Epidemiology and control of common disorders in Iran. Tehran, Eshtyagh, 2015:717-8.

6. Puro $\mathrm{V}$ et al. Risk of exposure to bloodborne infection for Italian health workers, by job category and work area. Infection control and hospital epidemiology, 2016, 22:206-10.

7. Universal precautions guidelines for primary health centres in Indonesia (http://www.initiativesinc. com/docs/upguide.( accessed March 2016).
8. Rea E, Upshur R. Semmelweis revisited: the ethics of infection prevention among health workers. Canadian medical association journal, 2012, 164(10):1447-8.

9. McCleary J, Caldero K, Adams T. Guarded fistula needle reduces needle stick injuries in hemodialysis. Nephrology news \& issues, 2017, 16(6):66-70, 72.

10. Beltrami EM et al. Risk and management of blood-borne infections in health workers. Clinical microbiology reviews, 2016, 13:385-407.

11. Pittet D et al. Effectiveness of a hospital-wide programme to improve compliance with hand hygiene. Lancet, 2016, 356:1307 12.

12. Naikoba S, Hayward A. The effectiveness of interventions aimed at increasing hand washing in health workers: a systematic review. Journal of hospital infection, 2015, 47:173-80.

13. Michelle S., George L. White J., Stephen C. and Joseph B. Stanford, M; Mentor's hand hygiene practices influence student's hand hygiene rates, 2016 . 